\title{
Actigenetic of ACE Gene Polymorphism in Czech Obese Sedentary Females
}

\author{
P. SUCHÁNEK ${ }^{1,2}$, J. A. HUBÁČEK ${ }^{1,2,3}$, I. KRÁLOVÁ LESNÁ ${ }^{1,2}$, V. PINEKEROVÁ ${ }^{1}$, \\ V. ADÁMKOVÁ ${ }^{1,3}$
}

${ }^{1}$ Institute for Clinical and Experimental Medicine, Prague, ${ }^{2}$ Centre for Cardiovascular Research, Prague, Czech Republic, ${ }^{3}$ South Bohemia University, Faculty of Public Health and Social Studies, Ceske Budejovice, Czech Republic

Received June 18, 2009

Accepted July 14, 2009

\section{Summary}

Obesity is a serious health problem worldwide and many genes have been implicated in determination of obesity, but our knowledge of the genes responsible for individual differences in weight loss after physical intervention are poor. One of the candidate genes is a gene for angiotensin-converting enzyme (ACE) ant its insertion/deletion (I/D) polymorphism. We have analyzed the association between the ACE gene variant in intervened obese females. Twenty four unrelated healthy obese (BMI > $29.9 \mathrm{~kg} / \mathrm{m}^{2}$, with abdominal type of obesity) premenopausal (age between 25 and 45 years) Czech Caucasian sedentary and non-diabetic females, pre-selected according the ACE I/D polymorphism (twelve II and twelve DD homozygotes) were studied in a medical research centre. They underwent 9 weeks intervention program (combination of the lowering of dietary intake to optimal level for the age and 3 times a week physical activity at fitness centre). The participants were supervised to sustain a heart rate of $65 \%$ of maximum. Anthropometrical, biochemical parameters and body composition (Bodystat 1500) were analyzed before and after the intervention. Our study suggest, that in Czech Caucasian females I/D polymorphism within the ACE gene will have no major effect on weight loss. Interestingly, we have detected, that in obese females II genotype was associated with higher increase in basal metabolic rate (202 kcal per day) then in DD homozygotes $(p<0.05)$, thus at least under some circumstances, this genetic variant may have an slight effect on BMI development.

\section{Key words}

ACE • Insertion/Deletion polymorphism • Physical activity • Body mass index

\section{Corresponding author}

Pavel Suchánek, Institute for Clinical and Experimental Medicine, Vídeňská 1958/9, Prague, Czech Republic.

FAX: +420 241721 574. E-mail: pasu@ikem.cz

\section{Introduction}

According to the latest surveys, the mean body mass index (BMI) in the Czech Caucasian population is approximately 27 (Bobak et al. 1999). The elevated body weight is a result of the imbalance between energy intake and energy expenditure. In most individuals, the decrease in BMI can be achieved through dietary changes and exercise. Nevertheless, the individual responses to lifestyle modification vary between individuals (Bouchard 2008).

Major factors, which may determine the effect of physical activity to BMI values, are the genetic factors. One of candidates is the angiotensin-converting enzyme (ACE) inhibitor gene and its insertion/deletion (I/D) polymorphism. ACE I/D polymorphism might play a role in the development of the obesity and the hypertension, which are closely linked to cardiovascular risk factors (Kitsios et al. 2009).

The inconsistent results obtained so far between the ACE I/D polymorphism and obesity, the blood pressure (BP), cardiovascular risk factors, and the insulin resistance may depend on ethnic background, sex or present disease of analysed individuals (Strazzullo et al. 2003). The angiotensin-converting enzyme gene (ACE) is 
the most frequently investigated gene in the context of genetic predispositions to high physical performance. The deletion allele of the human ACE gene is associated with higher ACE activity than the insertion allele. Previous studies have proved the connection between I/D polymorphism in the ACE gene and variable muscle strength responses to strength training (ST) (Charbonneau et al. 2008). ACE II genotype seems to be related with improvement in medium duration aerobic endurance performance whilst ACE DD genotype has an advantage for the performance enhancement in shorter duration and higher intensity endurance activities (Cam et al. 2008).

Further there is evidence that the I allele is associated with the improved endurance performance, as it was present in higher frequency than expected among high-altitude mountaineers (Montgomery et al. 1998) and Australian rowers (Gayagay et al. 1998), as well as the elite British distance runners (Myerson et al. 1999), Spanish (Alvarez et al. 2000), Russian (Nazarov et al. 2001) and Italian athletes (Scanavini et al. 2002) and South African-born triathletes (Collins et al. 2004). An opposite effect has been related to the $\mathrm{D}$ allele, seems to be more common amongst elite power-orientated athletes, such as sprinters (Myerson et al. 1999) and short-distance swimmers (Woods et al. 2001).

The previously reported associations of I and D alleles with endurance and sprint performance, respectively, have largely related to European and US Caucasian populations. On the basis of these reports, we assume that the effect of the regular aerobic physical activity on BMI changes, body composition changes and changes of lipid parameters would be dependent on the $\mathrm{I} / \mathrm{D}$ polymorphism of the ACE gene in the obese sedentary women.

\section{Material and Methods}

\section{Participant recruitment}

Twenty four unrelated healthy obese (BMI $>29.9$ $\mathrm{kg} / \mathrm{m}^{2}$, with abdominal type of obesity) premenopausal (age 25-45 years) Czech Caucasian sedentary and nondiabetic females, pre-selected according to ACE I/D polymorphism (twelve II and twelve DD homozygotes) were studied in a medical research centre. They signed informed consent and agreement to participate in the study, approved by the ethics committee. Exclusion criteria were: the presence of inflammatory or metabolic diseases (thyroid gland disease, any other endocrine disorders, autoimmune diseases, any chronic inflammation, or neoplastic disease).

\section{Study design}

The 9-week lifestyle modification program aimed to attain a balance between recommended dietary energy intake for the appropriate age and controlled physical activity. Dietary intervention (comprising a weekly, supervised dietary record) was aimed at adjust energy intake according to the amount recommended for the age (max. $8000 \mathrm{~kJ} /$ day, achieved mean was 7200 $\mathrm{kJ} /$ day), together with a decrease in animal fat (Králová Lesná et al. 2008) and dietary cholesterol intake (Dvořáková-Lorenzová et al. 2006). Participants were also encouraged to eat more fruits and vegetables. Additionally, the volunteers participated in a supervised 1-hour training session at a fitness centre 3 times weekly, and 3 more sessions per week (cycling, jogging or brisk walking) were recommended (at least 1 session was performed by all individuals). All these activities included an aerobic exercise component; the participants were supervised (and advised) to sustain a heart rate of 125-145 beats (according to age) per minute within $60 \mathrm{~min}$ exercise. The heart rate was continuously recorded telemetrically (Sport Tester S 410, RS 400, Polar Electro, Oy, Kempele, Finland).

\section{Anthropometric measurements}

Body weight was measured with an electronic weight scale (scaled to the nearest $100 \mathrm{~g}$ ) which was placed horizontally and calibrated before each weighting session. Height was measured with a stadiometer to the nearest $0.5 \mathrm{~cm}$. Waist (defined as narrowest diameter between xiphoid process and iliac crest) and hip (defined as widest diameter over the greater trochanters) circumferences were measured with the accuracy of $0.5 \mathrm{~cm}$. The waist-to-hip ratio and BMI were calculated from obtained measurements. Diastolic and systolic blood pressures were measured after $10 \mathrm{~min}$ in a sitting position as an average of 3 readings on the right arm with an automated blood pressure unit (automated sphygmomanometer BP-203 NA, Nippon Colin Co., Ltd.). Body composition, basal metabolic rate and estimated average requirement were determined by impedance analysis using a Bodystat analyzer (1500 MDD; Bodystat, Isle of Man, UK). A trained nurse performed all measurements. 
Table 1. Analysed parameters in the carriers of ACE II and DD genotypes at both the beginning and the end of the study.

\begin{tabular}{|c|c|c|c|}
\hline ACE DD & Basal & After 9 weeks & $\mathbf{p}$ \\
\hline Age, years & \multicolumn{2}{|c|}{$33.2 \pm 3.2$} & \\
\hline$B M I, \mathrm{~kg} / \mathrm{m}^{2}$ & $33.55 \pm 3.07$ & $31.82 \pm 3.32$ & $<0.001$ \\
\hline Weight, kg & $86.42 \pm 13.38$ & $81.99 \pm 12.87$ & $<0.001$ \\
\hline Waist, $\mathrm{cm}$ & $98.13 \pm 9.92$ & $92.63 \pm 10.1$ & $<0.001$ \\
\hline Waist-to-hip ratio & $0.84 \pm 0.03$ & $0.83 \pm 0.04$ & $<0.01$ \\
\hline Glycemia, $\mathrm{mmol} / \mathrm{l}$ & $5.41 \pm 0.60$ & $5.2 \pm 0.63$ & n.s. \\
\hline Total cholesterol, mmol/l & $4.69 \pm 0.95$ & $4.54 \pm 0.51$ & n.s. \\
\hline TGs, $\mathrm{mmol} / \mathrm{l}$ & $1.82 \pm 1.91$ & $1.44 \pm 0.71$ & n.s. \\
\hline HDL mmol/l & $1.58 \pm 0.44$ & $1.71 \pm 0.21$ & n.s. \\
\hline$L D L \mathrm{mmo} / \mathrm{l}$ & $2.58 \pm 0.51$ & $2.49 \pm 0.43$ & n.s. \\
\hline Systolic BP, mm Hg & $125.66 \pm 9.34$ & $116.23 \pm 7.51$ & $<0.001$ \\
\hline Diastolic BP, $\mathrm{mm} \mathrm{Hg}$ & $79.13 \pm 3.91$ & $75.15 \pm 5.14$ & $<0.001$ \\
\hline Heart rate, beat / $\mathrm{min}$ & $70.75 \pm 6.8$ & $64.13 \pm 7.45$ & $<0.001$ \\
\hline Total body fat, $\%$ & $35.16 \pm 4.54$ & $31.67 \pm 4.72$ & $<0.001$ \\
\hline Lean muscle mass, $\%$ & $63.37 \pm 8.25$ & $66.98 \pm 7.00$ & $<0.001$ \\
\hline Basal metabolite rate, $k c a l / d a y$ & $1722 \pm 165$ & $1799 \pm 235$ & $<0.001$ \\
\hline Basal metabolic rate/body weight, $\mathrm{kcal} / \mathrm{kg}$ & $20.83 \pm 1.96$ & $21.90 \pm 2.03$ & $<0.001$ \\
\hline Estimated average energy requirement, kcal/day & $2604 \pm 232$ & $2743 \pm 242$ & $<0.001$ \\
\hline
\end{tabular}

\begin{tabular}{|c|c|c|c|}
\hline ACE II & Basal & After 9 weeks & $\mathbf{p}$ \\
\hline Age, years & \multicolumn{2}{|c|}{$34.7 \pm 5.3$} & \\
\hline$B M I, \mathrm{~kg} / \mathrm{m}^{2}$ & $32.89 \pm 2.71$ & $30.88 \pm 4.11$ & $<0.001$ \\
\hline Weight, kg & $90.12 \pm 16.22$ & $83.15 \pm 13.66$ & $<0.001$ \\
\hline Waist, $\mathrm{cm}$ & $100.65 \pm 11.48$ & $94.89 \pm 12,51$ & $<0.001$ \\
\hline Waist-to-hip ratio & $0.85 \pm 0.04$ & $0.84 \pm 0.03$ & $<0.01$ \\
\hline Glycemia, mmol/l & $5.23 \pm 0.54$ & $4.99 \pm 0.47$ & n.s. \\
\hline Total cholesterol, mmol/l & $4.96 \pm 1.29$ & $4.81 \pm 1.09$ & n.s. \\
\hline$T G s, \mathrm{mmol} / \mathrm{l}$ & $1.96 \pm 2.13$ & $1.65 \pm 0.98$ & n.s. \\
\hline HDL mmol/l & $1.35 \pm 0.31$ & $1.39 \pm 0.36$ & n.s. \\
\hline$L D L \mathrm{mmo} / \mathrm{l}$ & $3.04 \pm 1.25$ & $2.93 \pm 1.07$ & n.s. \\
\hline Systolic BP, mm Hg & $119.14 \pm 5.67$ & $116.23 \pm 7.51$ & $<0.001$ \\
\hline Diastolic BP, $\mathrm{mm} \mathrm{Hg}$ & $74.14 \pm 8.03$ & $70.14 \pm 8.78$ & $<0.001$ \\
\hline Heart rate, beat /min & $72.71 \pm 8.24$ & $64.00 \pm 7.83$ & $<0.001$ \\
\hline Total body fat, $\%$ & $38.39 \pm 4.58$ & $33.54 \pm 5.71$ & $<0.001$ \\
\hline Lean muscle mass, $\%$ & $59.95 \pm 3.99$ & $65.81 \pm 4.42$ & $<0.001$ \\
\hline Basal metabolite rate, $k c a l / d a y$ & $1477 \pm 539$ & $1756 \pm 172$ & $<0.001$ \\
\hline Basal metabolite rate, kcal/day & $19.21 \pm 1.96$ & $21.95 \pm 1.47$ & $<0.001$ \\
\hline Estimated average energy requirement, kcal/day & $2391 \pm 293$ & $2768 \pm 280$ & $<0.001$ \\
\hline
\end{tabular}

ANOVA of repeated measures was performed in order to evaluate the statistical significance of differences between baseline and postintervention values. No significant differences (n.s.) were observed comparing basal and post-intervention results ( $p>0.05$ ). LDL $=$ Lowdensity lipoprotein; HDL = high-density lipoprotein; TGs = triglycerides; BP = blood pressure 


\section{Biochemical assays}

Plasma triacylglycerol, total cholesterol and cholesterol in high-density (HDL-C) and low-density (LDL-C) fractions were measured enzymatically by a standardized procedure (Centres for Disease Control and Prevention external quality control system), using the Cobas Mira analyzer (Hoffman-LaRoche).

\section{Genotyping and DNA assays}

DNA was isolated from frozen EDTA blood using a standard method (Miller et al. 1988). Analyses of ACE I/D polymorphism were performed using the polymerase chain reaction according to the previously described standard protocol (Rigat et al. 1993). To avoid the possible misgenotyping of some I/D heterozygotes, primers according to Yoshida et al. (1996) have been used for the second - insertion specific - amplification of all samples with recognised D/D homozygosity from the first genotyping.

\section{Statistical analysis}

The differences in lipids, anthropometric parameters, body composition, basal metabolic rate and estimated average requirement were evaluated using ANOVA test. All data were presented as mean \pm SD. Differences were considered to be statistically significant if $\mathrm{p}<0.05$.

\section{Results and Discussion}

In the all obese screened females, frequencies of ACE I/D genotypes were similar to the general Czech population (Hubáček et al. 1999). Analyzed parameters obtained in selected individuals at the baseline and after the intervention are presented in Table 1 . We have ascertained a significant influence of diet to the most of anthropometrical and lipid parameters but both groups do not differ substantially. No difference of decrease in BMI between II and DD homozygotes (6.12\% by II homozygotes and $5.1 \%$ by DD homozygotes) and no significant association between waist-to-hip ratio changes and ACE genotypes have been determined. No difference in changes between other anthropometrical and lipid parameters has been noted in females with different ACE genotypes. We have observed significant differences in response to body exercises in individual participants with ACE II and DD, i.e. the increase of their lean muscle mass $(p<0.05)$. The increase of muscle mass has been a result of the increase of basal metabolic rate, basal metabolic rate per kilogram body weight and average energy requirement $(p<0.05)$. This difference could be based on the fact of increased basal metabolism i.e. it is higher in II homozygotes (202 kcal per day) then in DD homozygotes $(\mathrm{p}<0.05)$.

Generally, we have detected no ACE I/D based differences in anthropometrical and biochemical parameters at the start of our study and after doing body exercises. We have observed differences in body composition - according to above II carriers increased more theirs basal metabolism (basal metabolic rate), basal metabolic rate per kilogram body weight and energy requirement per day in comparison with DD carriers. However, these changes were not accompanied by corresponding decrease in BMI or WHR values. Unfortunately, we don't have information's about the energy intake of participants and we can not exclude the possibility, that II homozygotes also have higher coloric intake in comparison to the DD homozygotes. The strength of dietary-exercise intervention was defined as aerobic in acceptable frequency and was, as expected, more profitable for II homozygotes. Thus it would be suitable to regulate the physical activity of obese individuals according theirs $\mathrm{I} / \mathrm{D}$ polymorphism within the ACE gene. Insertion/deletion polymorphism in ACE gene is one of the most intensively analysed candidates to genetic determination of physical endurance. Although some studies have found that II genotype is associated with better reaction on physical activity, other studies have not found the same. Studies so far published underline the importance of inter-population differences. Our study suggests that I/D polymorphism within the ACE gene will have no major effect on weight loss in Czech Caucasian females. Interestingly, we have detected that II genotype was associated with a higher increase of basal metabolism in obese females - thus this genetic variant may have a slight effect on BMI development at least under some circumstance.

\section{Conflict of Interest}

There is no conflict of interest.

\section{Acknowledgements}

This work was supported by grant NR/9393-3 (IGA, Ministry of Health of the Czech Republic. We thank to the study participants. 


\section{References}

ALVAREZ R, TERRADOS N, ORTOLANO R, IGLESIAS-CUBERO G, REGUERO JR, BATALLA A, CORTINA A, FERNANDEZ-GARCIA B, RODRIGUEZ C, BRAGA S, ALVAREZ V, COTO E: Genetic variation in the renin-angiotensin system and athletic performance. Eur J Appl Physiol 82: 117-120, 2000.

BOBAK M, HERTZMAN C, ŠKODOVÁ Z, MARMOT M: Socioeconomic status and cardiovascular risk factors in the Czech Republic. Int J Epidemiol 28: 46-52, 1999.

BOUCHARD C: Gene-environment interactions in the etiology of obesity: defining the fundamentals. Obesity (Silver Spring) 16 (Suppl 3): S5-S10, 2008.

CAM S, COLAKOGLU M, COLAKOGLU S, SEKURI C, BERDELI A: ACE I/D gene polymorphism and aerobic endurance development in response to training in a non-elite female cohort. $J$ Sports Med Phys Fitness 47: 234-238, 2007.

CHARBONNEAU D, HANSON ED, LUDLOW A, DELMONICO MJ, HURLEY BF, ROTH SM: ACE genotype and the muscle hypertrophic and strength responses to strength training. Med Sci Sports Exerc 40: 677-683, 2008.

COLLINS M, XENOPHONTOS SL, CARIOLOU MA, MOKONE GG, HUDSON DE, ANASTASIADES L, NOAKES TD: The ACE gene and endurance performance during the South African Ironman Triathlons. Med Sci Sports Exerc 36: 1314-1320, 2004.

DVOŘÁKOVÁ-LORENZOVÁ A, SUCHÁNEK P, HAVEL P, STÁVEK P, KARASOVÁ L, VALENTA Z, TINTĚRA J, POLEDNE P: The decrease in C-reactive protein concentration after diet and physical activity induced weight reduction is associated with changes in plasma lipids, but not interleukin-6 or adiponectin. Metabolism 55: 359-365, 2006.

GAYAGAY G, YU B, HAMBLY B, BOSTON T, HAHN A, CELERMAJER DS, TRENT RJ: Elite endurance athletes and the ACE I allele - the role of genes in athletic performance. Hum Genet 103: 48-50, 1998.

HUBÁČEK JA, PIŤHA J, ADÁMKOVÁ V, LANSKÁ V, POLEDNE R: Insertion deletion polymorphism in the angiotensin convertig enzyme gene in the Czech population. (in Czech) Cas Lek Ces 138: 622-625, 1999.

KATAN MB, BEYEN AC, DE VRIES JH, NOBELS A: Existence of consistent hypo- and hyperresponders to dietary cholesterol in man. Am J Epidemiol 123: 221-234, 1986.

KITSIOS G, ZINTZARAS E: ACE (I/D) polymorphism and response to treatment in coronary artery disease: a comprehensive database and meta-analysis involving study quality evaluation. BMC Med Genet 10: 50, 2009.

KRÁLOVÁ LESNÁ I, SUCHÁNEK P, KOVÁŘ J, STÁVEK P, POLEDNE R: Replacement of dietary saturated FAs by PUFAs in diet and reverse cholesterol transport. J Lipid Res 49: 2414-2418, 2008.

MILLER SA, DYKES DD, POLESKY HF: A simple salting out procedure for extraction DNA from human nucleated cells. Nucleic Acid Res 16: 1215, 1988.

MONTGOMERY HE, MARSHALL R, HEMINGWAY H, MYERSON S, CLARKSON P, DOLLERY C, HAYWARD M, HOLLIMAN DE, JUBB M, WORLD M, THOMAS EL, BRYNES AE, SAEED N, BARNARD M, BELL JD, PRASAD K, RAYSON M, TALMUD PJ, HUMPHRIES SE: Human gene for physical performance. Nature 393: 221-222, 1998.

MYERSON S, HEMINGWAY H, BUDGET R, MARTIN J, HUMPHRIES S, MONTGOMERY H: Human angiotensin I-converting enzyme gene and endurance performance. J Appl Physiol 87: 1313-1316, 1999.

NAZAROV IB, WOODS DR, MONTGOMERY HE, SHNEIDER OV, KAZAKOV VI, TOMILIN NV, ROGOZKIN VA: The angiotensin converting enzyme I/D polymorphism in Russian athletes. Eur J Hum Genet 9: 797-801, 2001.

RIGAT B, HUBERT C, CORVOL P, SUBRIER F: PCR detection of the insertion/deletion polymorphism of the human angiotensin converting enzyme gene (DCP1) (dipeptidyl carboxypeptidase 1). Nucl Acids Res 20: 1433, 1993.

SCANAVINI D, BERNARDI F, CASTOLDI E, CONCONI F, MAZZONI G: Increased frequency of the homozygous II ACE genotype in Italian Olympic endurance athletes. Eur J Hum Genet 10: 576-577, 2002.

STRAZZULLO P, IACONE R, IACOVIELLO L, RUSSO O, BARBA G, RUSSO P, D'ORAZIO A, BARBATO A, CAPPUCCIO FP, FARINARO E, SIANI A: Genetic variation in the renin-angiotensin system and abdominal adiposity in men: the Olivetti Prospective Heart Study. Olivetti Prospective Heart Study. Ann Intern Med 138: 17-23, 2003. 
YOSHIDA H, KURIYAMA S, ATSUMI Y, TOMONARI H, MITARAI T, HAMAGUCHI A, KUBO H, KAWAGUCHI Y, KON V, MATSUOKA K, ICHIKAWA I, SAKAI O: Angiotensin I converting enzyme gene polymorphism in non-insulin dependent diabetes mellitus. Kidney Int 50: 657-664, 1996.

WOODS D, HICKMAN M, JAMSHIDI Y, BRULL D, VASSILIOU V, JONES A, HUMPHRIES S, MONTGOMERY H: Elite swimmers and the D allele of the ACE I/D polymorphism. Hum Genet 108: 230-232, 2001. 